\title{
FAKTOR BIOTIK DAN ABIOTIK YANG MENDUKUNG KERAGAMAN TUMBUHAN PAKU(Pteridophyta) DI KAWASAN HUTAN GISTING PERMAI KABUPATEN TANGGAMUS LAMPUNG
}

\author{
Sri Wahyuningsih ${ }^{1}$, Achyani ${ }^{2}$, Handoko Santoso ${ }^{3}$ \\ ${ }^{1}$ MTS Negeri 2 Gunung Alip Tanggamus ${ }^{2,3}$ Universitas Muhamamadiyah Metro \\ Email: sriwn1980@gmail.com ${ }^{1}$, acysbd@gmail.com ${ }^{2}$, handoko.umm@gmail.com ${ }^{3}$
}

\begin{abstract}
Abstrak: Tumbuh suburnya Pteridophyta di Kawasan Hutan Gisting Permai Kecamatan Gisting Kabupaten Tanggamus sangat dipengaruhi oleh faktor biotik dan abiotik. Faktor biotik meliputi semua kehidupan makhluk hidup di bumi baik individu, populasi dan komunitas yang di dalamnya termasuk jumlah inang Pteridophyta yang banyak, sedangkan faktor abiotik meliputi seluruh faktorfaktor non hidup dari suatu kondisi lingkungan seperti cahaya matahari, suhu, air, dan tanah, ketinggian. Faktor-faktor abiotik ini tidak hanya menyediakan energi dan materi penting, tetapi juga mempunyai peranan dalam menentukan tumbuhan-tumbuhan dan hewan-hewan yang mampu berada disuatu tempat tertentu sesuai dengan habitatnya. Metode yang digunakan dalam kajian ini adalah berupa kajian kualitatif. Artikel ini dikaji dengan menyatukn referensi dari berbagai sumber diantaranya berasal dari jurnal, buku, arsip dokumen pekon Gisting Permai, dan internet. Pengumpulan data diperoleh dengan menggunakan berbagai referensi yang dikumpulkan sebanyak mungkin yang berkaitan dengn faktor biotik dan abiotik pertumbuhan tumbuhan paku.
\end{abstract}

Kata kunci: Biotik, Abiotik, Pteridophyta.

Abstrack: The growth of Pteridophyta in the Gisting Permai Forest Area, Gisting Sub-District Tanggamus Regency was strongly influenced by biotic and abiotic factors. Biotic factors include all the life of living things on earth both individuals, populations and communities which include a large number of Pteridophyta hosts, while abiotic factors include all non-living factors of an environmental condition such as sunlight, temperature, water, and soil, height. These abiotic factors not only provide important energy and material, but also had a role in determining plants and animals that which are able to be in a certain place according to their habitat. The method used in this study is a qualitative study. This article was reviewed by citing references from various sources including journals, books, Gisting Permai archive documents, and the internet. The data collection was obtained by using as many references as possible related to biotic and abiotic factors for fern growth. Key word: biotic, abiotic, Pteridophyta.

\section{How to Cite}

Wahyuningsih, Sri, Achyani, dan Handoko Santoso. 2021. Faktor Biotik Dan Abiotik yang Mendukung Keragaman Tumbuhan Paku (Pteridophyta) Di Kawasan Hutan Gisting Permai Kabupaten Tanggamus Lampung. Biolova 2(1). 64-71. 
Dalam kehidupan makhluk hidup ada salah satu kebutuhan yang sangat dibutuhkan yaitu hutan, karena Hutan merupakan paru-paru bumi yang sangat berperan sebagai habitat berbagai satwa, vegetasi, hasil tambang dan berbagai sumber daya lainnya yang tak ternilai harganya bagi makhluknya.

Berdasarkan pasal 7, Peraturan Menteri Kehutanan Nomor P.37/Menhut-11/2007 tentang Hutan Kemasyarakatan, sebagaimana telah beberapa kali diubah dengan Peraturan Menteri Kehutanan Nomor P.52/Menhut-II/2011 tentang Areal Kerja Hutan Kemasyarakatan yang ditetapkan oleh menteri berada pada kawasan Hutan Lindung dan Kawasan Hutan Produksi yang belum dibebani hak atau izin dalam pemanfaatan hasil hutan, dan menjadi sumber mata pencaharian masyarakat setempat (Permenhut : No P.52 2011).

Penetapan

Kemasyarakatan berdasarkan surat Direktur Jendral Planologi Kehutanan Nomor S.1315/V11-WP3H/2012 tanggal 7 November 2012, setelah dilakukan telaah pada peta dan perhitungan luas terhadap kawasan karya rimba komunitas di Gisting Kabupaten Tanggamus Lampung dengan luas pengukuran digital seluas \pm 4.305 (empat ribu tiga ratus lima) Hektar yang seluruhnya berada pada Kawasan Hutan Lindung(KHL). HKM merupakan rimba negara melalui prosedur penyelenggaraan rimba yang mempunyai arah memanfaatkan penduduk ( menumbuhkan nilai ekonomi, nilai budaya, mempersembahkan kegunaan terhadap penduduk pekerja, dan masyarakat setempat), tanpa mengganggu fungsi pokoknya yaitu meningkatkan fungsi hutan dan fungsi kawasan, pemanfaatan kawasan, pemanfaatan jasa lingkungan, pemanfaatan hasil hutan kayu, hasil hutan bukan kayu dengan tetap menjaga fungsi kawasan hutan (Cahyaningsih,2006) .

Kecamatan

Gisting mempunyai 9 pekon yang salah satunya adalah Pekon Gisting Permai yang terletak di tiga kilometer menuju Barat dari kabupaten Kecamatan dan memiliki luas kawasn $\pm 460 \mathrm{Ha}$. Desa Gisting Permai mempunyai batasbatas sebagai berikut:

- Bagian Utara bersebelahan dengan Desa Gisting Atas

- Bagian Selatan bersebelahan dengan Desa Batukeramat

- Bagian Barat bersebelahan dengan Hutan lindung register 30

- Bagian Timur bersebelahan dengan Hutan lindung skedul 28.

Berfungsinya peranan hutan di alam ini apabila keanekaragaman tumbuhan dapat tumbuh bersama, namun untuk mencapai hal itu banyak banyak faktor yang mendukungnya contohnya Tumbuh suburnya Pteridophyta yang berada di Kawasan Hutan Gisting Permai Kecamatan Gisting Kabupaten Tanggamus yang dipengaruhi oleh unsur hidup dan tak hidup. Faktor hidup terdiri dari seluruh aktivitas benda tak mati di alam baik tunggal, kelompok dan sekumpulan yang di dalamnya termasuk jumlah inang Pteridophyta yang banyak, sedangkan faktor tak hidup terdiri dari semua faktorfaktor tak hidup dari suatu situasi alam semacam sinar mentari, temperatur, air, tanah, ketinggian atau topografi, kelembapan dan Garis Lintang.

Faktorfaktor mati ini tidak hanya mencadangkan kalor dan bahan berguna, namun juga memiliki manfaat dalam memastikan tumbuhantumbuhan dan hewanhewan yang dapat terletak di lokasi tertentu sama dengan tempat tinggal. 
Artikel ini mengkaji tentang: 1) Faktor biotik yang dapat mendukung keragaman tumbuhan paku di kawasan hutan Gisting Permai. 2) Faktor abiotik yang dapat mendukung kergaman tumbuhan paku di kawasan hutan Gisting Permai, 3) Indeks keragaman tumbuhan paku di kawasan hutan Gisting Permai.

\section{METODE}

Artikel ini dikaji berupa kajian dari referensi berbagai sumber diantaranya berasal dari jurnal, buku, dan arsip dokumen pekon Gisting Permai, dan internet.

\section{PEMBAHASAN}

\section{Tumbuhan Paku}

Tumbuhan paku merupakan suatu divisi yang warganya telah jelas mempunyai Kormus, yaitu tubuhnya dengan nyata dapat dibedakan dalam tiga bagian utama yaitu akar, batang dan daun, namun pada tumbuhan paku belum dihasilkan biji (Darma :2007). Gawai reproduksi tanaman pakis yang pokok yaitu serbuk.

Berdasarkan

metode

bernapasnya tanaman pakis ada yang bernyawa di air (hidrofit), hidup di tempat lembab (higrofit), hidup menempel pada tumbuhan lain (epifit) dan ada yang hidup pada sisa-sisa tumbuhan lain atau sampahsampah (saprofit) (Tjitrosoepomo, 2005) .

Pada perputaran bernapasnya, tanaman pakis mendapati pergantian turunan (metagenesis) antara keturunan gametofit yang berkromosom tunggal (n) dan keturunan sporofit yang berkromosom ganda (2n). Keturunan sporofit bernapas lebih menyeluruh atau mempunyai waktu bernapas yang lebih lama ibarat keturunan gametofit.

Dalam taksonomi, tumbuhan paku termasuk ke dalam divisi Pteridophyta yang terbagi menjadi Psilophytinae (paku purba), Lycopodiinae (paku kawat), Equisetinae (paku ekor kuda) dan Filicinae (paku sejati) (Tjitrosoepomo, 2005) .

\section{Morfologi Tumbuhan Paku}

Akar tumbuhan paku pada embrionya mampu diperbedakan diukur dua ujung yakni ujung vertikal dan horizontal. Ujung vertikal mau bersemi membentuk pucuk (batang beserta daundaunnya). Ujung horizontal diberi nama ujung rimpang. Ujung rimpang tidak lanjut bersemi membentuk rimpang. Akar tumbuhan paku bersifat endogen dan tumbuh ke samping dari batang. Akar yang keluar pertama-tama tidak dominan, melainkan segera disusul oleh akar-akar lain yang semuanya muncul dari batang (Tjitrosoepomo, 2005) .

Pokok ktu tanman pakis kadangkadang tak nampak. Seyogyanya bagaikan tanaman pada biasanya, tanaman pakis mempunyai rimpang model pakis yang bernapas di tanah, pokok kayu itu bersemi searah dengan tanah. Karena berseminya yang menyamai rimpang inilah pokok kayu itu dinamakan rhizoma. pokok kayu ini acap dilindungi dengan bulu atau jangat yang berperan untuk melindunginya. Mulai rhizoma ini juga bersemi akarakar yang halus

Dahan pakis ada yang sendiri ada yang berkelompok, bahkan ada yang menjari genap. Potongan dahan tersebut dengan keseluruhan acap dinamakan daging. Daging dalam pucuk tanaman pakis umumnya melingkar sehingga dinamakan coil atau gelung. Daging meliputi stipe, rachis dan lamina.

Serbuk dalam tanaman pakis sangat halus Sporaspora ini 
diproduksi oleh kotak serbuk dan tersimpan rapatrapat di isinya. jenisjenis tanaman yang memproduksi serbuk mempunyai rumah tunggal dan sama besar disebut pakis homospor atau isospor.

Tanaman

(Pteridophyta)

dengan vegetatif

Berkembangbiak

dilakukan dengan pembentukan serbuk dengan pemisahan meiosis sel induk serbuk yang terletak pada sporangium (kotak serbuknya).

Serbuk mau bersemi berubah gametofit. Disamping dengan pembuatan serbuk, berkembangbiak dengan vegetatif pula mampu dikerjakan melalui rizom. Rizom mau bersemi merayap dan membuat tunastunas tanaman pakis yang berkelompok. Perkembangbiakan generatif dikerjakan menggunakan pembuahan sel telur oleh spermatozoid berekor yang memproduksi zigot. Zigot itu akan bersemi dengan sporofit.

Komponen Biotik Berpengaruh terhadap Pertumbuhan Tumbuhan Paku

\section{Kompetisi:}

Pada anggota tanaman, terjadi persaingan diantara individuindividu baik antar jenis yang tidak beda maupun antar jenis yang tidak sama. Seandainya untuk mencari materi hara, mineral, tanah, air, sinar dan tempat bersemi. Persaingan akan mengakibatkan terjadinya tumpukan anggota tanaman yang bercirikan dari segi bentuk, jumlah jenis dan jumlah individu-individu penyusunnya sesuai dengan keadaan tempat tumbuh dan habitatnya (Ardhana :2012) .

\section{Penjenjangan:}

Penjenjangan tajuk adalah tumpukan tanaman dengan meninggi pada suatu kelompok tanaman. Terlampaui disebabkan dua aspek utama yang dilalui tanaman pada perlawanan hidupnya dengan taanaman lain. Kesatu karena kompetisi antar tanaman timbullah jenis batang yang dapat berkompetisi, tinggi, keras dan menjadi jenis yang menyeluruh diibaratkan oleh jenis lainnya. Yang berikutnya yaitu disebabkan ciri jenis batang kepada pancaran sinar mentari. Spesiesspesies batang yang tidak simpati memperoleh giliran lokasi bersemi yang pesat, panjang batangnya mencapai letak sangat vertikal. Namun batang intoleran yang terlindungi oleh pohon lainnya, maka pertumbuhannya akan terlambat dan kemungkinan besar tidak akan bertahan hidup pada hutanhutan yang sangat lebat dan akhirnya mati (Ardhana :2012) .

\section{Interaksi Perlawanan}

Persekutuan hidup alam hayati termasuk di dalamnya tumbuhtumbuhan dan hewan terjadi secara komplek saling memengaruhi bahkan terjadi hubungan simbiosis mutualisme ataupun terjadi antagonestik, parasit, epifit, mikoriza, nodul akar dan sebagainya (Ardhana :2012) .

\section{Menempel}

Menempel adalah seluruh tanaman yang melekat dan bersemi dalam tanaman lainnya guna memperoleh sinar mentari dan cairan. Seperti Asplenium nidus dan A.africanum adalah jenis tanaman pakis yang bersemi melekat dalam pokok kayu dan cabangcabang batang.

\section{Tanaman Benalu}

Tanaman benalu merupakan tanaman yang melekat dalam tanaman lain dan menangkap nutrisi dalam tanaman induk. Tanaman benalu 
dikelompokkan menjadi dua yaitu semi benalu (nutrisi separo dari induk separo didapatkan dari pembuatan makanan masing-masing) dan total benalu (hidup bergantung seluruhnya dalam tanaman induk).

\section{Fungi}

Fungi merupakan jamur rimpang yang menyesuaikan interaksi simbiosis mutualisme antara fungi (mykos) dan

perimpangan (rhizos) tanaman yang paling pokok sel paling luar dan paling dalam. Fungi mendapatkan nutrisi organik pokok glukosa dari tanaman, sementara serapan nutrisi hara dan cairn mampu berjalan lebih maksimal.

\section{Benjolan Rimpang}

Benjolan rimpang tersusun dari obsesi nitrogen simbiotik yang dikerjakan rhizobium melalui leguminosae. Benjolan rimpang merupakan susunan simbiosis mutualisme antara bakteri Rhizobium spp dan rimpang tanaman

\section{Hewan Rimba}

Hewan rimba merupakan belahan yang tak mampu dibagi dua oleh anggota tanaman. kecuali berfungsi untuk pemakan hewan pula berfungsi pada pembuahan contohnya tawon, berbagai jenis unggas dan kalong.

\section{Unsur Tak Hidup Berpengaruh terhadap Pertumbuhan Tumbuhan Paku}

Faktor abiotik memiliki pengaruh yang sangat besar terhadap kehidupan komponen biotik (Novianti, 2006) . Faktor abiotik diantaranya:

\section{Sinar Mentari}

Pancaran Sinar Mentari menyiapkan kalor leluasa yang diperlukan tumbuhan guna membuat makanan sediri. Pancaran memiliki dampak fotokimia dan kalor dalam tanaman. Foton (partikel dasar pancaran elektromagnet) dari sinar dengan panjang gelombang 400$700 \mathrm{~nm}$ bisa mengakibatkan proses fotokimia pada pembuatan makanan oleh tumbuhan hijau. Foton dari sinar pula mampu mengakibatkan fotokimia pada molekul berbeda karena perbedaan pertumbuhan pada tanaman. Pertumbuhan pohon rentan dengan panjang hari dari hasil sinar. Dampak sinar dari cahaya pada tanaman bergantung dengan besar energi sinar dan kesetimbangan energi.

Tanaman mempunyai situasi ruang bersemi dalam responnya terhadap selang batas nilai cahaya tertentu. Bagi umumnya tumbuhan intensitas cahaya optimum untuk proses fotosintesis haruslah lebih kecil dari intensitas cahaya matahari penuh.

\section{Temperatur}

Tempertur adalah penyebab rung sekitar yang mampu berfungsi baik dengan spontan maupun tak langsung kepada benda hidup. Bermanfaat spontan mirip dengan tiap manfaat dari tanaman dengan meninjau jalannya prosesproses kimia pada tanaman, sementara fungsi tidak langsung dengan membujuk faktorfaktor lainnya yang sangat utama adalah penyediaan air. Menurut Leopold (1964) suhu optimum untuk fotosintesis berkisar antara $10-30^{\circ} \mathrm{C}$, diatas atau di bawah suhu tersebut laju fotosintesa berkurang, tetapi juga tergantung pada jenis tanaman . Temperatur umumnya kurang lebih sama dengan temperatur sekelilingnya karena adanya pergantian temperatur yang terus menerus antara tanaman dan udara sekelilingnya. 
Air

Air merupakan unsur alam yang utama, seluruh makhluk hidup membutuhkan air. Untuk tanaman air sanagat utama sebab mampu menguasai masa hidupnya Bahkan air adalah bagian dari unsurr iklim yang paling berpengaruh kepada pertumbuhan dan perubahan tatanan dan organ tumbuhan.

Air adalah sebagian terbesar penyususun jaringan dari seluruh makhluk hidup bagi tumbuhan. Antara $40 \%$ sampai $60 \%$ dari berat segar pohon terdiri dari air dan bagi tumbuhan herba totalnya mungkin akan sampai 90\%. Guna pendukung, tanaman membutuhkan air bagi pendukung jaringan-jaringan yang tidak mengandung kayu. Apabila selsel jaringan ini memiliki banyak air maka selsel ini selalu dalam kondisi kuat. Penekanan yang dilahirkan dengan munculnya air dalam sel dinamakan tekanan turgor dan sel akan berkembang. Jika jumlah air tidak mencukupi maka tekanan turgor pasti berkurang dan isi sel akan mengecil dan munculah plasmolisis. Untuk media pengangkutan, tanaman menggunakan air untuk media membawa zat disekeliling tubuhnya. Unsur meresap bersama rimpang dan menuju ke wilayah tumbuhan lainnya untuk substansi yang hancur dalam air.

\section{Lahan}

pertanian bergantung dengan

kegemburan lahan dan cara-cara penggunaan serta pengerjaan lahan itu. Keadaan fisik lahan memastikan penetrasi akarakar didalam lahan, retensi air, drainase, aerasi, unsur tanaman, serta mempengaruhi sifatsifat kimia dan biologi tanah. Sejumlah ciri fisika lahan yang sangat utama yaitu kandungan, struktur, prioritas dan konsistensi. Tanah yang kandungannya sedang adalah yang terbaik. Jika kandungannya terlalu lembut mengandung sangat banyak air, sehingga udara tanahnya tidak kebagian celah pori lagi dan mengakibatkan tanaman semakin mendapatkan defisiensi air. kemudian pohon akan menjadi lambat dalam menyerap air dan unsurunsur hara yang ada. Kebutuhan lahan dipengaruhi oleh kandungan alat organik, struktur dan kandungan tanah.

\section{Ketinggian atau Topografi}

Dataran atas suatu lokasi memastikan jenis makhluk hidup yang bernapas di lokasi itu, sebab ketinggian yang tidak sama akan melahirkan keadaan fisik dan kimia yang tidak sama pula.

\section{Udara}

Udara disamping berfungsi sebagai penentu kelembapan juga berfungsi pada sebaran biji tumbuhan tertentu.

\section{Garis Khayal}

Garis khayal yang berbeda mewujudkkan keadaan alam yang tidak sama juga. Garis khayal secara garis besar mengakibatkan keadaan yang tidak sama distribusi makhluk hidup di hamparan bumi. Sejumlah makhluk hanya mampu bertahan pada garis lintang tertentu saja.

\section{Keadaan basah}

Keadaan basah adalah salah satu unsur tak hidup di udara dan tanah. Keadaan basah di udara berarti kandungan uap air di udara, sedangkan kedaan basah di tanah berarti kandungan air dalam tanah. lembab dibutuhkan oleh makhluk hidup agar tubuhnya tidak mudah kering adanya penguapan. Kelembaban yang diperlukan setiap maklhuk hidup tidak sama. contohnya, 
jamur dan cacing memerlukan tempat tinggal yang sangat basah.

\section{Garam-Garam Mineral}

Garam-garam mineral meliputi ion-ion nitrogen, fosfat, sulfur, kalsium, dan natrium. Komposisi garam-garam mineral tertentu memastikan ciri tanah dan air. Contohnya kandungan ionion hydrogen menentukan tinggi rendahnya $\mathrm{pH}$, sementara kandungan ion natrium dan klorida di air menentukan tingkat salinitas (kadar garam). Tumbuhan mengambil garamgaram mineral (unsur hara) dari tanah dan air guna proses pembuatan makanan oleh tumbuhan hijau.

\section{Manfaat Tumbuhan Paku}

Tumbuhan pakis ternyata mempunyai beragam kegunaan untuk kehidupan organisme di sekelilingnya walaupun tumbuhan pakis tidak banyak yang suka, tetapi masih banyak penduduk yang memelihara tumbuhan pakis diantaranya sebagai hiasan, sebagai obat-obatan, sebagai sayuran, sebagai bahan pembuatan karangan bunga, sebagai pupuk hijau, sebagai bahan pembuatan petasan, tiang bangunan, dan sebagai penggosok atau ampelas

Tumbuhan paku memiliki cara hidup yang bemacam-macam, ada yang saprofit, contohnya: Jamur, epifit, contonya: Paku Sarang burung (Asplenium nidus), Paku Kaki Tupai (Davallia trichomanoides), Paku Sisik naga (Drymoglossum piloselloides), Paku Harupat (Nephrolephis biserrata), Paku Sepat (Nephrolephis cordifolia), Paku Tanduk rusa (Platyceriumifurcatum), Polypodium billardieri, Polypodium glycyrriza, Paku Tamaga (Asplenium belangeri ), Polypodium verrucosu higrofit, contohnya: Suplir (Adiantum sp) Simbar menjangan (Platycerium oronarium), Paku tanduk rusa
(Platycerium bifurcatum), Paku Harupat (Nephrolepis sp.), Paku Jantan/Paku Kayu (Dryopteris sp), Paku Tanah (Pteris vittata $s p$ ), Semanggi (Marsileacrenata), atau hidrofit, contohnya: Semanggi (Marsilea sp.), Kiambang (Salvinia sp.), Azolla (Azolla sp.)(IDP Darma, 2007).

\section{KESIMPULAN}

Dari data di atas maka dapat diambil kesimpulan bahwa ternyata di kawasan Hutan Gisting Permai Kecamatan Gisting Kabupaten Tanggamus Lampung tersimpan kekayaan yaitu berupa keanekaragaman jenis tumbuhan paku yang dapat dijadikan sumber informasi belajar biologi bagi dunia pendidikan khususnya bagi siswa dan berbagai ragam manfaat bagi masyarakat luas dengan didukung oleh faktor biotik berupa produsen, konsumen dan pengurai, serta faktor abiotik berupa: air, tanah, suhu atau temperatur, kelembapan, garis lintang, angin dan garam mineral.

\section{SARAN}

Dari uraian yang telah disampaikan di atas maka perlu adanya penelitian yang memuat informasi tentang jenis hewan atau jenis tumbuhan lain yang terdapat di Kawasan Hutan Gisting Permai Kecamatan Gisting Kabupaten Tanggamus Lampung sehingga dapat bermanfaat bagi dunia pendidikan.

\section{DAFTAR LITERATUR}

Ardhana, IPG. 2012. Ekologi

Tanaman. Denpasar: Udayana University press.

Cahyaningsih, N. Pasya, G. dan Warsito. 2006. Hutan Kemasyarakatan Kabupaten Lampung Barat : Panduan Metode Memproses Ijin dan Cara Sukses Menghadapi 
Evaluasi. Buku. Penerbit.

Lampung. $87 \mathrm{hlm}$.

Darma, I. D. P. \& Peneng, I. N. 2007. Inventarisasi Tumbuhan Paku di

Kawasan Taman Nasional Laiwangi-Wanggameti Sumba Timur, aingapu, Nusa Tenggara Timur. Jurnal Biodiversitas. 8 (3):242-248.

Dirjen Planologi, 2012. Direktur Jendral Planologi Kehutanan Nomor. $\quad$ 1315/V11WP3H/2012.

Novianti, Putri Frida, 2006 .Laporan Ekologi Pertanian Faktor Biotik Dan Abiotik

Menhut. 2007. Permenhut Nomor P.37 Tahun 2007 Tentang Hutan Kemasyarakatan. Jakarta: Permenhut.

Menhut. 2011. Permenhut Nomor P.52 Tahun 2011 Tentang Areal Kerja Hutan Kemasyarakatan. Jakarta : Permenhut.

Menhut. 2014. Permenhut Nomor P.88 Tahun 2014 Tentang Kawasan Hutan LIndung Kemasyarakatan. Jakarta : Permenhut.

https://nikiberliana27.blogspot.com /2017/0 2/faktor-biotikdan- abiotik- ekologi.html

Tjitrosoepomo, G, 2005, Taksonomi Tumbuhan(Schizophyta, Thallophyta, Bryophyta, Pteridophyta),

Yogyakarta, Gajah Mada University Press. 